\title{
Upaya Meningkatkan Kemampuan Komunikasi Verbal Melalui Metode Sosiodrama Pada Anak Usia 5-7 Tahun
}

\author{
Robiyatul Adewiyah ${ }^{1}$ Evy Fitria ${ }^{2}$ \\ ${ }_{1,2}$ Program Studi Pendidikan Guru Pendidikan Anak Usia Dini; Fakultas \\ Keguruan Dan Ilmu Pendidikan; Universitas Muhammadiyah Tangerang \\ Email : radewiyah20@gmail.com, 2evyfitria@gmail.com
}

\begin{abstract}
Abstrak
Penelitian ini bertujuan untuk meningkatkan kemampuan komunikasi verbal melalui metode sosiodrama pada anak usia 5-7 tahun di RA.Manbaul Hikmah Rawalini Teluknaga Kabupaten Tangerang. Metode penelitian yang digunakan adalah Penelitian Tindakan Kelas (PTK) yang dilakukan sebanyak 3 (tiga) Siklus. Prosedur penelitian ini terdiri dari 4 (empat) tahap, yaitu Perencanaan, Tindakan, Observasi dan Refleksi. Metode pengumpulan data dalam penelitian ini menggunakan observasi, wawancara dan dokumentasi. Subyek penelitian ini adalah peserta didik usia 5-7 tahun di kelompok B1 dimana anak-anak mengalami masalah dalam komunikasi verbalnya, seperti pengucapkan kosakata, berbicara dan menanggapi pembicaraan, berpartisipasi dalam percakapan, berargumentasi berupa komentar dan membuat tulisan-tulisan. Hasil penelitian menunjukkan bahwa terjadi peningkatan kemampuan komunikasi verbal melalui metode sosiodrama. Kemampuan komunikasi verbal pada Siklus I mencapai $60 \%$, Siklus II meningkat mencapai $76 \%$ dan meningkat lebih baik lagi pada Siklus III mencapai 95\%.
\end{abstract}

Kata Kunci : Sosiodrama, Komunikasi verbal, Anak Usia 5-7 Tahun

\section{Pengantar}

Masa usia dini merupakan masa yang sangat menentukan bagi perkembangan dan pertumbuhan anak selanjutnya karena merupakan masa peka dan masa emas dalam kehidupan anak. Hal ini mengisyaratkan bahwa semua pihak perlu memahami akan pentingnya masa usia dini untuk optimalisasi pertumbuhan dan perkembangan.

Berdasarkan Undang-undang Nomor 20 Tahun 2003 tentang Sistem Pendidikan Nasional berkaitan dengan pendidikan Anak Usia Dini tertulis pada 
"Ceria"

Jurnal Program Studi Pendidikan Anak Usia Dini

pasal 28 ayat 1 yang berbunyi “Pendidikan Anak Usia Dini diselenggarakan bagi anak sejak lahir sampai dengan enam tahun dan bukan merupakan prasyarat untuk mengikuti pendidikan dasar". Selanjutnya pada Bab 1 pasal 1 ayat 14 ditegaskan bahwa Pendidikan Anak Usia Dini adalah suatu upaya pembinaan yang ditujukan kepada anak sejak lahir sampai dengan usia enam tahun yang dilakukan melalui pemberian rangsangan pendidikan untuk membantu pertumbuhan dan perkembangan jasmani dan rohani agar anak memiliki kesiapan dalam memasuki pendidikan lebih lanjut (Kemendikbud, 2015).

Dengan demikian Pendidikan Anak Usia Dini dapat dikatakan salah satu bentuk penyelenggaraan pendidikan yang menitikberatkan pada peletakkan dasar ke arah pertumbuhan dan perkembangan fisik (koordinasi motorik halus dan kasar), kecerdasan (daya pikir, daya cipta, kecerdasan emosi, kecerdasan spiritual), sosio emosional (sikap dan perilaku serta beragama), bahasa dan komunikasi, sesuai dengan keunikan dan tahap-tahap perkembangan yang dilalui oleh anak usia dini (Susanto, 2017, h.4).

Pada lembaga pendidikan anak usia dini, anak-anak sudah diajarkan dasar-dasar cara belajar. Tentunya di usia dini, mereka akan belajar pondasipondasinya. Mereka diajarkan dengan cara yang mereka ketahui, yakni lewat bermain. Bukan sekadar bermain, tetapi bermain yang bermakna. Lewat bermain yang bermakna, mereka bisa belajar banyak, cara bersosialisasi, problem solving, negosiasi, manajemen waktu, resolusi konflik, berada dalam grup besar/kecil, kewajiban sosial, serta 1-3 bahasa.

Pada usia 5-7 tahun, anak juga menunjukkan minatnya yang berlebih pada teman-temannya. Ia akan mulai menunjukkan hubungan dan kemampuan bekerja sama yang lebih intens dengan teman-temannya. Kemampuan komunikasi yang baik dapat anak-anak peroleh dari aktivitas yang sangat dekat dengan dunianya, yaitu melalui bermain. Anak memilih teman berdasarkan kesamaan aktivitas dan kesenangan. Selain dari itu, kualitas lain dari anak usia 
"Ceria"

Jurnal Program Studi Pendidikan Anak Usia Dini

dini untuk memahami pembicaraan dan pandangan orang lain semakin meningkat sehingga keterampilan komunikasinya juga meningkat.

Salah satu aspek perkembangan yang harus menjadi perhatian penuh dari pihak guru maupun orang tua yaitu perkembangan komunikasi. Bermain merupakan alat yang paling kuat untuk membelajarkan kemampuan bahasa anak. Melalui komunikasi inilah anak dapat memperluas kosa kata dan mengembangkan daya penerimaan serta pengekspresikan kemampuan berbahasa mereka melalui interaksi dengan anak-anak lain dan orang dewasa pada situasi bermain spontan.

Komunikasi verbal adalah komunikasi yang menggunakan kata-kata, entah lisan maupun tulisan (Ngalimun, 2016, h.19). Komunikasi ini paling banyak dipakai dalam hubungan antar manusia. Melalui kata-kata, mereka mengungkapkan perasaan, emosi, pemikiran, gagasan, atau maksud mereka, menyampaikan fakta, data, dan informasi serta menjelaskannya, saling bertukar perasaan dan pemikiran, saling berdebat, dan bertengkar.

Karakteristik kemampuan komunikasi verbal anak usia 5-7 tahun diantaranya menurut Jamaris dalam Susanto (2011, h.78): 1) Penggunaan kosakata anak memiliki lingkup yang luas, 2) dapat berbicara dan menanggapi pembicaraan, 3) Dapat berpartisipasi dalam percakapan, dan 4) Dapat berargumentasi berupa komentar, 5) Membuat tulisan-tulisan. Pada usia 5-7 tahun penggunaan kosa kata memiliki lingkup yang luas. Lingkup kosakata yang dapat diucapkan anak menyangkut warna, ukuran, bentuk, rasa, bau, keindahan, kecepatan, suhu, perbedaan, perbandingan, jarak, dan permukaan (kasar-halus). Anak usia 5-7 tahun juga sudah dapat melakukan peran sebagai pendengar yang baik.

Selain itu, anak usia 5-7 tahun dapat berpartisipasi dalam suatu percakapan. Anak sudah dapat mendengarkan orang lain berbicara dan menanggapi pembicaraan tersebut. Percakapan yang dilakukan oleh anak 5-6 
"Ceria"

Jurnal Program Studi Pendidikan Anak Usia Dini

tahun telah menyangkut berbagai komentarnya terhadap apa yang dilakukan oleh dirinya sendiri dan orang lain, serta apa yang dilihatnya.

Metode sosiodrama merupakan metode mengajar dengan cara mempertunjukkan kepada peserta didik. Sosiodrama merupakan sebuah teknik pemecahan masalah yang terjadi dalam konteks tentang masalah-masalah hubungan sosial, untuk mencapai tujuan pengajaran tertentu. (Aqib, dkk, 2016, h.185). Dalam hal ini, metode sosiodrama menuntut kualitas tertentu pada peserta didik, yaitu peserta didik diharapkan mampu menghayati tokoh-tokoh atau posisi yang dikehendaki. Keberhasilan peserta didik dalam menghayati peran itu akan menentukan apakah proses pemahaman, penghargaan, dan identifikasi diri terhadap nilai berkembangnya.

Bermain sosiodrama akan membawa anak mengalami perasaan positif, artinya anak bisa menikmati dan meniru tokoh sesuai yang diperankan oleh anak. Metode sosiodrama salah satu solusi untuk mengatasi permasalahan anak karena dengan memerankan tokoh-tokoh dalam cerita anak akan mengeluarkan pendapatnya.

Berdasarkan hasil observasi awal anak didik kelompok B usia 5-7 Tahun di RA. Manbaul Hikmah Rawalini Teluknaga Kabupaten Tangerang, diperoleh fakta bahwa permasalahan yang dihadapi yaitu diantaranya, anak-anak yang belum bisa berinteraksi dengan teman sebayanya. Anak-anak tersebut cenderung kurang mengungkapkan perasaannya, belum dapat meluapkan emosi serta gagasan dan lebih senang bermain sendiri.

Selain itu, anak kurang mengungkapkan pendapatnya sendiri. Anak lebih banyak mendengarkan guru dan mengerjakan tugas-tugas yang diberikan oleh guru. Mereka kurang mengungkapkan pendapatnya sendiri sehingga anak lebih banyak menerima informasi daripada pengeluarkan pendapatnya. Bila masalah ini tidak segera mendapat solusi maka sangatlah sulit hasil belajar anak didik mencapai prestasi yang memuaskan terutama bahasa yang dimiliki anak rendah dikelas. Sehingga dapat mengakibatkan bahasa dan kosa kata yang dimiliki anak 
"Ceria"

Jurnal Program Studi Pendidikan Anak Usia Dini

terbatas. Rendahnya bahasa dan kosa kata anak juga dapat menghambat proses belajar, karna anak lebih cenderung diam dan sulit berkomunikasi dengan temannya.

Permasalahan yang lain yaitu penggunaan metode pembelajaran klasikal yang kurang bervariasi dan menarik yang membuat anak didik menjadi pasif, karena lebih banyak mendengarkan dan menerima penjelasan dari guru. Guru lebih banyak menggunakan pembelajaran klasikal dari pada pembelajaran praktik langsung. Kurangnya komunikasi anak juga disebabkan karena adanya bilingual, terutama setelah mereka mengenal media televisi dan memasuki dunia pendidikan. Lingkungan tidak selalu sesuai dengan keinginannya sehingga mereka harus belajar menyesuaikan diri dengan tuntutan lingkungannya termasuk perkembangan bahasa penting untuk anak.

Pola asuh orangtua yang lebih membiarkan anak asyik dengan berbagai media di rumah. Salah satunya medium televisi. Melalui televisi anak banyak menonton sinetron yang kerap menampilkan adegan yang bermasalah dan negatif. Tak heran kalau anak-anak kecil sekarang sudah berani marah kepada orangtua seperti yang mereka lihat di televisi. Hal ini menyebabkan komunikasi yang dilakukan anak, berperilaku kasar dan tidak sehat. Begitu juga dengan gadget.

Dengan kegiatan sosiodrama melalui sebuah permainan yang melibatkan anak didik untuk dapat berperan dan dapat berhubungan antara peran satu dengan yang lainnya, dalam suatu peragaan yang dapat memerankan tokoh tertentu yang terdapat dalam kehidupan sosial masyarakat sekitar. Dalam kegiatan sosiodrama terjadi aktivitas berbahasa melalui dialog atau percakapan, sehingga dapat meningkatkan kemampuan berkomunikasi verbal dan berbahasa pada anak usia 5-7 Tahun.

\section{Metode}

Metode penelitian yang digunakan dalam penelitian ini adalah Penelitian Tindakan Kelas (PTK), dengan subjek penelitian yaitu anak usia 5-7 tahun di 
"Ceria"

Jurnal Program Studi Pendidikan Anak Usia Dini

RA.Manbaul Hikmah Rawalini Teluknaga Kabupaten Tangerang. Menurut

Salahudin (2015, h.24) penelitian tindakan kelas adalah penelitian praktis untuk memperbaiki pembelajaran di dalam kelas. Penelitian ini merupakan salah satu upaya guru atau praktisi dalam bentuk berbagai kegiatan yang dilakukan untuk memperbaiki dan meningkatkan mutu pembelajaran di kelas. Dalam Penelitian Tindakan Kelas ini, tindakan yang dilakukan adalah meningkatkan kemampuan komunikasi verbal melalui metode sosiodrama pada anak usia 5-7 tahun, dengan fokus pada indikator pengucapan kosakata memiliki lingkup yang luas, berbicara dan menanggapi pembicaraan, berpartisipasi dalam percakapan, berargumentasi berupa komentar dan membuat tulisan-tulisan.

Desain penelitian yang digunakan adalah model Kurt Lewin. Konsep pokok action research menurut Kurt Lewin dalam Salahudin (2015, h.30) terdiri atas empat komponen, yaitu perencanaan (planning), tindakan (acting), pengamatan (observing), dan refleksi (reflecting). Hubungan keempat komponen tersebut dipandang sebagai satu siklus. Instrumen yang digunakan dalam penelitian ini yaitu berupa lembar penilaian berupa daftar checklist, catatan wawancara, catatan lapangan serta dokumentasi.

\section{Hasil dan Pembahasan}

Peningkatan kemampuan komunikasi verbal anak dalam penelitian ini dilakukan dengan metode sosiodrama dalam tiga siklus, setiap siklus terdiri dari empat pertemuan. Kemampuan komunikasi verbal anak diukur berdasarkan lima indikator yaitu pengucapan kosakata memiliki lingkup yang luas, berbicara dan menanggapi pembicaraan, berpartisipasi dalam percakapan, berargumentasi berupa komentar dan membuat tulisan-tulisan.

Penerapan kemampuan komunikasi verbal yang dilakukan peneliti menggunakan alat dan bahan serta membahas tema yang berbeda pada setiap siklus. Pada Siklus I tema yang dibahas adalah Keluarga dengan Sub Keluargaku. Alat dan bahan yang digunakan adalah meja, kursi dan alat-alat rumah tangga. 
"Ceria"

\section{Jurnal Program Studi Pendidikan Anak Usia Dini}

Hasil pengamatan pada Siklus I Peneliti mengamati anak-anak mulai terlihat antusias dalam kegiatan pembelajaran, khususnya dalam kegiatan sosiodrama atau bermain peran. Permainan sosiodrama atau bermain peran diikuti oleh semua anak. Semua anak dapat ikut serta dalam memainkan peran yang sesuai dengan tema. Pengamatan dilakukan dengan menggunakan observasi terbuka berupa catatan kegiatan yang ditulis dalam catatan lapangan berdasarkan proses yang terjadi dari awal sampai akhir kegiatan dan lembar instrument komunikasi verbal anak usia 5-7 tahun.

\section{Grafik 1}

Hasil Observasi Siklus I Kemampuan Komunikasi Verbal

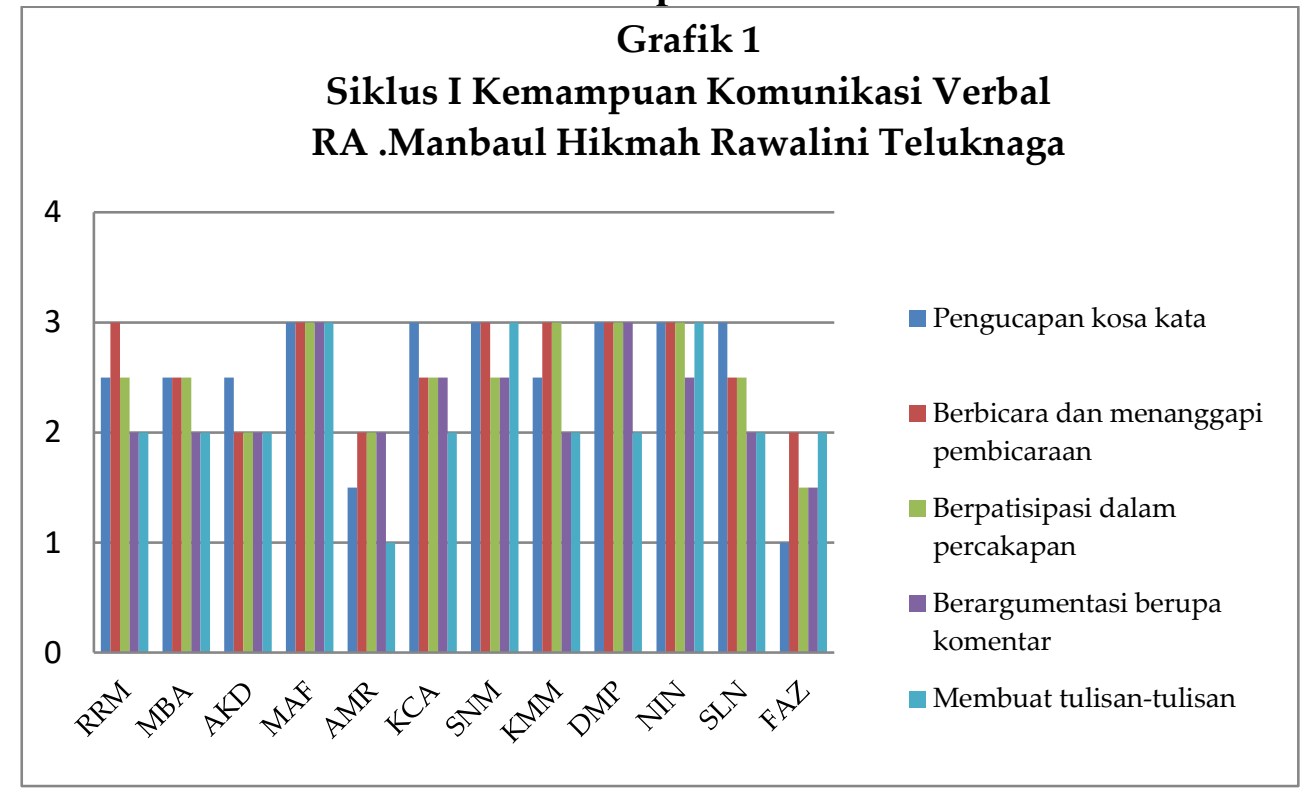

Pada Siklus ini terdapat 1 anak yang mencapai indikator keberhasilan yaitu MAF, sehingga pencapaian indikator keberhasilan kemampuan komunikasi verbal anak usia 5-7 tahun baru mencapai 8,3\%, sehingga perlu dilaksanakan siklus berikutnya yaitu siklus II.

Berdasarkan temuan tersebut, peneliti melakukan perbaikan pada siklus II agar hasil yang dicapai dapat lebih optimal. Peneliti menambahkan variasi dalam memainkan peran dan alat serta bahan yang digunakan anak agar dapat berkomunikasi verbal lebih luas. Pada siklus II tema yang dibahas adalah Pasar dengan sub tema toko sayuran, buah, sepatu dan pakaian). 
"Ceria"

Jurnal Program Studi Pendidikan Anak Usia Dini

Berdasarkan pengamatan yang dilakukan pada siklus II, terlihat sudah ada peningkatan dari cukup menjadi baik, pada saat proses kegiatan pembelajaran dengan indikator pengucapan kosakata memiliki lingkup yang luas, berbicara dan menanggapi pembicaraan, berpartisipasi dalam percakapan, berargumentasi berupa komentar dan membuat tulisan-tulisan.

Grafik 2

Hasil Observasi Siklus II Kemampuan Komunikasi Verbal

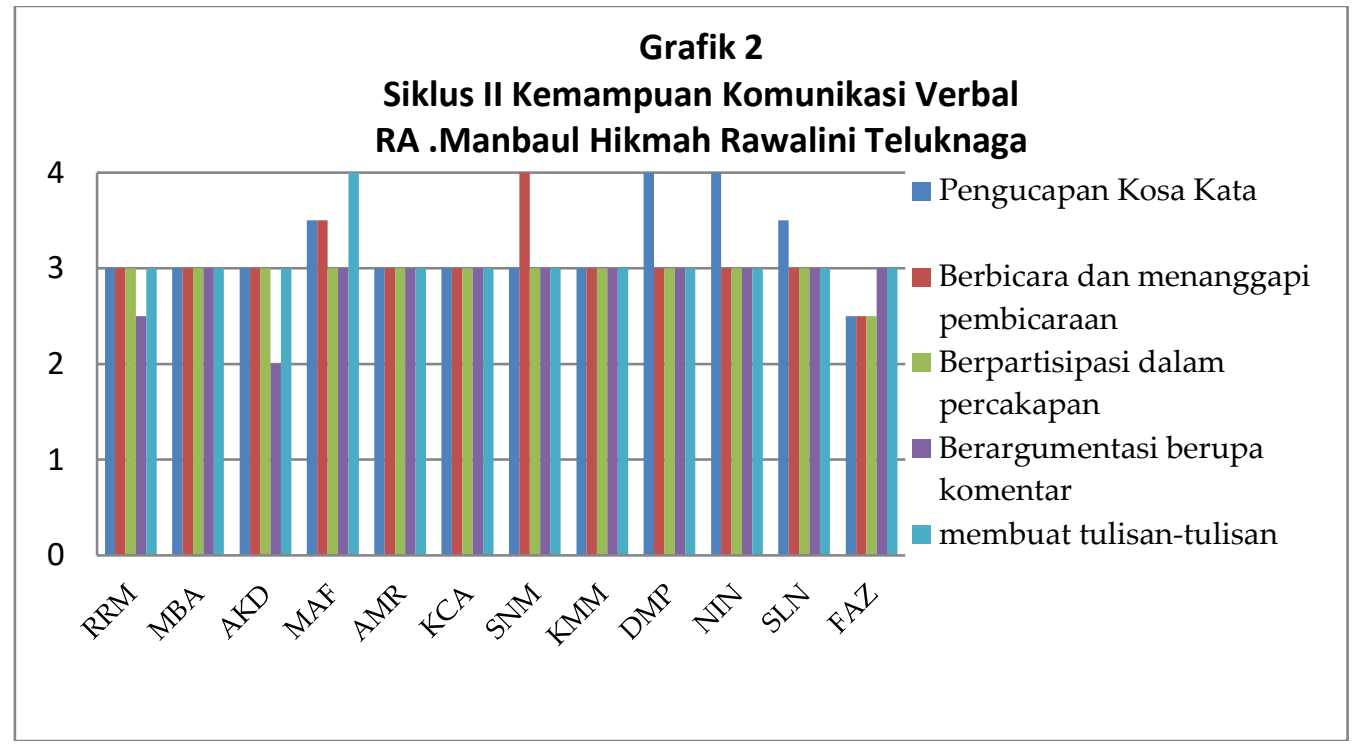

Pada Siklus ini terdapat 8 anak yang mencapai indikator keberhasilan yaitu MBA, MAF, KCA, SNM, KMM, DMP, NIN dan SLN sehingga pencapaian indikator keberhasilan kemampuan komunikasi verbal anak usia 5-7 yang sudah dicapai sebesar 67\%, dengan demikian masih perlu dilaksanakan siklus berikutnya yaitu siklus III.

Berdasarkan temuan diatas, peneliti kembali melakukan perbaikan pada siklus III agar dapat mencapai hasil yang lebih baik. Peneliti menambahkan variasi alat dan bahan dalam kegiatan sosiodrama. Pada siklus III tema yang dibahas adalah Profesi dengan sub tema Dokter gigi, perawat, polisi dan guru.

Berdasarkan pengamatan yang dilakukan pada siklus III, terlihat adanya perbaikan baik hasil belajar maupun proses belajar, meningkatnya kemampuan 
"Ceria"

\section{Jurnal Program Studi Pendidikan Anak Usia Dini}

komunikasi verbal anak menjadi sangat baik. Hal tersebut ditunjukkan dari presentase peningkatan yang ada.

\section{Grafik 3}

Hasil Observasi Siklus III Kemampuan Komunikasi Verbal

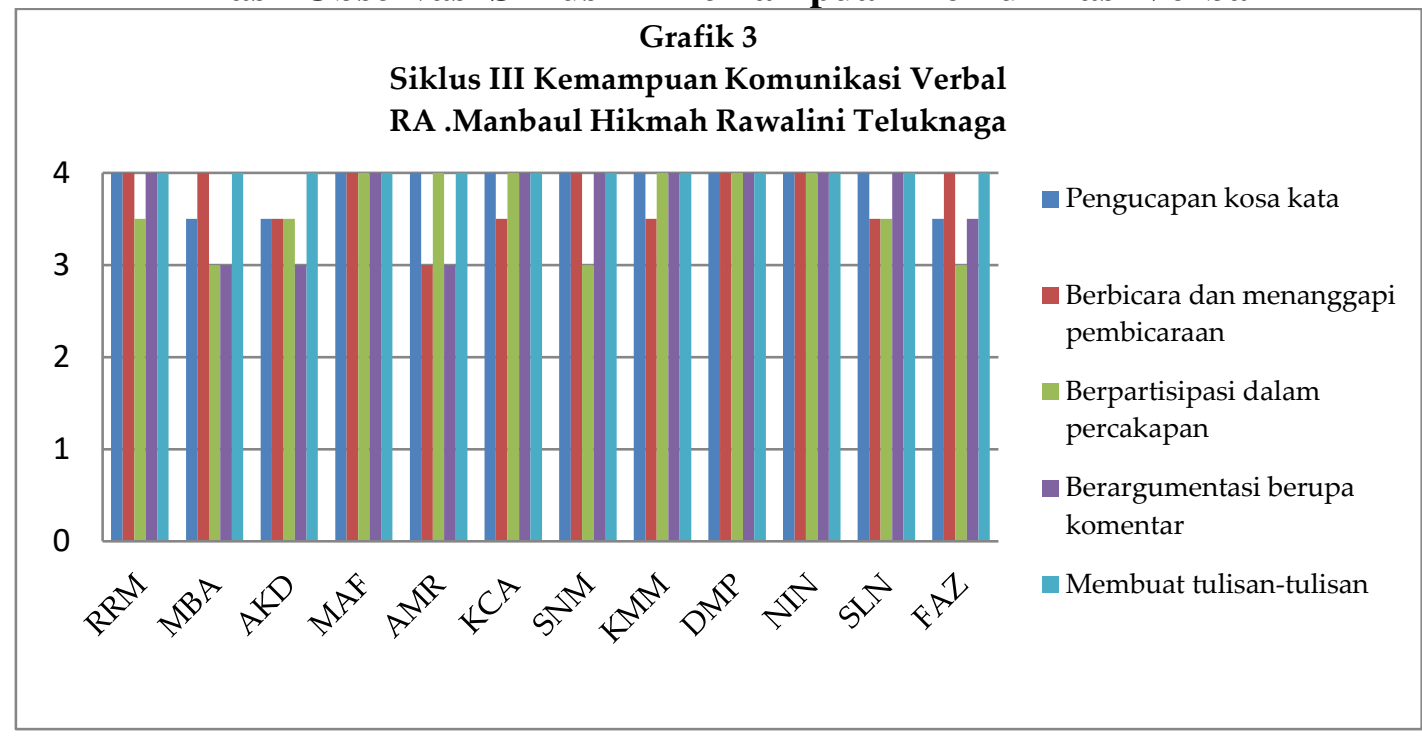

Pada Siklus ini terdapat 12 anak yang mencapai indikator keberhasilan yaitu RRM, MBA, AKD, MAF, AMR, KCA, SNM, KMM, DMP, NIN, SLN dan FAZ sehingga pencapaian indikator keberhasilan kemampuan komunikasi verbal anak usia 5-7 yang sudah mencapai sebesar 100\%. Seluruh anak dapat meningkat kemampuan komunikasi verbalnya dengan tercapainya indikator keberhasilan secara maksimal. Dengan demikian penelitian ini tidak perlu dilaksanakan pada siklus berikutnya dan tindakan berhenti pada siklus III.

Berdasarkan paparan hasil data terkait kemampuan komunikasi verbal di atas dapat diketahui bahwa metode sosiodrama memberikan perkembangan dalam kemampuan pengucapan kosakata memiliki lingkup yang luas, berbicara dan menanggapi pembicaraan, berpartisipasi dalam percakapan, berargumentasi berupa komentar dan membuat tulisan-tulisan.

\section{Kesimpulan}

Berdasarkan hasil penelitian yang telah dilaksanakan maka dapat ditarik kesimpulan bahwa melalui metode sosiodrama dapat meningkatkan kemampuan 
"Ceria"

Jurnal Program Studi Pendidikan Anak Usia Dini

komunikasi verbal pada anak usia 5-7 tahun di RA.Manbaul Hikmah Rawalini Rawalini Teluknaga. Hal tersebut ditandai adanya peningkatan kemampuan komunikasi verbal anak dimana pada kondisi awal 45\%, siklus I sebesar 60\%, pada siklus II sebesar 76\%, dan pada siklus III sebesar 95\%. Sehingga presentase kenaikan dari pra siklus ( kondisi awal ) ke siklus I adalah sebesar15\%, presentase kenaikan dari siklus I ke siklus II sebesar 16\%, dan presentase kenaikan dari siklus II kesiklus III adalah19\%.

Terbuktinya hipotesis tindakan menunjukkan bahwa apabila guru Taman Kanak-kanak atau Raudhatul Athfal menggunakan metode sosiodrama dalam proses pembelajaran maka kemampuan komunikasi verbal pada anak usia 5-7 tahun akan meningkat. Persiapan ruangan dalam bentuk pengaturan sedemikian rupa perlu dilakukan guru, agar menciptakan lingkungan belajar yang menarik dan menyenangkan bagi anak untuk dapat meningkatkan kemampuan komunikasi verbal.

Media juga perlu dipersiapkan dengan baik agar menumbuhkan minat anak untuk melaksanakan kegiatan. Dalam pelaksanaan kegiatan pembelajaran guru harus memberikan kesempatan bagi anak untuk berekspresi mengembangkan gagasan dan perasaannya baik secara lisan maupun tertulis dalam lembar kerja anak. Guru juga harus menjadi model pada proses pembelajaran karena anak belajar dari model yang ditampilkan oleh guru.

\section{Daftar Acuan}

Aqib, Z \& Murtadlo, A. (2016). Kumpulan Metode Pembelajaran. Bandung: Satu Nusa.

Kemendikbud. (2015). Permendikbud Nomor 137 tentang Standar Nasional Pendidikan Anak Usia Dini.

Ngalimun. (2016). Ilmu Komunikasi Sebuah Pengantar Praktis. Yogyakarta: Pustaka Baru Press.

Salahudin, Anas. (2015).Penelitian Tindakan Kelas. Bandung: Pustaka Setia.

Susanto, Ahmad. (2011). Perkembangan Anak Usia Dini. Jakarta: Kencana. 
"Ceria"

Jurnal Program Studi Pendidikan Anak Usia Dini

Susanto, Ahmad. (2017). Pendidikan Anak Usia Dini Konsep dan Teori. Jakarta:

Bumi Aksara. 